\title{
Wealth Discrimination Theory
}

\author{
James Edward Curtis Jr. ${ }^{1}$ \\ ${ }^{1}$ James Edward Curtis Jr Education Foundation, Washington, USA \\ Correspondence: James Edward Curtis Jr., James Edward Curtis Jr Education Foundation, Washington, DC \\ 20010, USA.
}

Received: July 25, 2018

Accepted: July 29, 2018

Online Published: August 8, 2018

doi:10.20849/iref.v2i2.443

URL: https://doi.org/10.20849/iref.v2i2.443

\begin{abstract}
One approach to analyzing inequality is to compare average economic choices from a classical theoretical framework. Another approach considers the impact of the formation of society, through statutes and institutions, on average economic outcomes. This paper studies the effects of slavery on black-white wealth inequality upon the emancipation of slaves in the US using historical data.

The purpose of wealth has varied from over time. From an economics perspective, wealth is the accumulation of resources that have market value and can be liquidated for present and future consumption. This study proceeds based on the most measurable assumption: households reside in a country with a mixed economy of markets and social planning, such that they have an incentive to accumulate material wealth for intertemporal household consumption and social influence. Becker (1957) and Arrow (1972) developed the most general theories of wage discrimination and favoritism. Oaxaca (1973) and Blinder (1973) have mechanized their theories for empirical analysis. While their findings are insightful, they cannot be directly applied to studying wealth differences since wealth is a complex combination of wages and other variables.

Finally, since unexplained differences in states that abolished slavery after the Civil War were 10 percent higher than unexplained effects in states that abolished slavery well before the Civil War and the magnitudes of the unexplained effects were similar over the long-run, we cannot reject the existence of a negatively bounded correlation between the duration of time from enslavement and the magnitude of unexplained differences in wealth.

This research was funded in part by the National Science Foundation under Grant SES 0096414. I would like to thank John Ham, Richard Steckel, Randall Olsen, Bruce Weinberg, Audrey Light, Nori Hashimoto, James Peck, Patricia Reagan, Charles Kirwin, Rebecca Blank, Charles Betsey, Alvin Thornton, Leibert Morris, Maude Toussaint-Comeau, Simone Wegge, James Wilbanks, Thomas Maloney, and William Collins for their insightful comments. I would also like to thank participants in workshops and seminars at the Ohio State University, Howard University, University of Michigan, American Economic Association Summer Program and Pipeline Conferences, Western Economics Association International meetings, and Social Science History Association meetings. I would also like to thank James Curtis Sr, K D Curtis, Karen Curtis (deceased), Lariece Grant-Brown, Barbara Broadnax, Dwayne Broadnax, Rudy Broadnax, Zee Curtis-Grant, Raymond Tillery, Chris Cooper, Dr. K A Troy, Dr. H. Beecher Hicks, Reverend Charles Lewis, Reverend Cornelius Wheeler, Reverend James Lewis, Elder David Treadwell, Dr. Stephen Tucker and Roberta Tucker, Minister Charles Webb, Minister David Surles, and Elder Gregory Strong for their support. This draft is a revision of a November 2010 paper and August 2001 paper.
\end{abstract}

Keywords: wealth discrimination, economic inequality

\section{Introduction}

Many individuals look to a higher source of power, such as the holiness expressed in the King James Version of the Holy Bible, for a source of direction (i.e., Genesis 1:1; Genesis 1:27; Exodus 20:2-17; John 1:1; Romans 3:23-25, 1 Corinthians 6:12a), strength (i.e., Philippians 4:6,13; Hebrews 11:1), purpose (i.e., Jeremiah 29:11; 1 Corinthians 13:13), and provision (i.e., Matthew 6:33; Philippians 4:11; Hebrews 11:6). Since the days of old, differences in creation existed, for instance, the Holy Bible reads "Servants be obedient" (Ephesians 6:5). But it also reads "ye Masters, do the same ... knowing your Master also is in heaven; neither is there respect of persons with him" (Ephesians 6:9). Seemingly juxtapositional scriptures, as read, suggest the issue of inequality in 
provisions among creation is monitored by the divinity expressed in holy documents, such as the Holy Bible. This produces an incentive to derive robust explanations for experiential differences in observed phenomena among creation and recommendations for progress.

The following is a skeleton review of literature, with supplemental discussions in Appendix C; a definition and theory of economic discrimination, with supplemental discussions in Appendix A and Appendix B; econometrics; measurements of economic discrimination; regression decomposition results; conclusions; and references.

\section{Literature}

Entering the 21st Century, Table 1 shows Blacks, Hispanics and women still have reduced labor market experiences relative to white men.

Table 1. Recent labor market statistics across race, ethnicity \& gender

\begin{tabular}{|c|c|c|c|c|c|c|}
\hline & \multicolumn{3}{|c|}{ Males } & \multicolumn{3}{|c|}{ Females } \\
\hline & White & Black & Hispanic & White & Black & Hispanic \\
\hline \multicolumn{7}{|l|}{$1995 \%$ of White Male: } \\
\hline Hourly Wage & 19 & $66 \%$ & $64 \%$ & $65 \%$ & $54 \%$ & $58 \%$ \\
\hline Annual Earnings & $\$ 36,200$ & $65 \%$ & $57 \%$ & $57 \%$ & $49 \%$ & $43 \%$ \\
\hline Weeks Worked & 42 & $81 \%$ & $91 \%$ & $81 \%$ & $74 \%$ & $62 \%$ \\
\hline Hours/Week Worked & 38 & $79 \%$ & $90 \%$ & $73 \%$ & $69 \%$ & $58 \%$ \\
\hline \multicolumn{7}{|l|}{1997 Percentage: } \\
\hline LFP Rate & $78 \%$ & $72 \%$ & $84 \%$ & $60 \%$ & $64 \%$ & $57 \%$ \\
\hline Unemployment Rate & $4 \%$ & $9 \%$ & $6 \%$ & $4 \%$ & $9 \%$ & $8 \%$ \\
\hline College Degree + & $27 \%$ & $13 \%$ & $11 \%$ & $22 \%$ & $14 \%$ & $10 \%$ \\
\hline
\end{tabular}

Source: Calculations from 1995 CPS data reported in Table 1 on page 3147 from Altonji and Blank, "Race and Gender in the Labor Market," in Handbook of Labor Economics edited by Ashenfelter and Card, 1999; Borjas, 1999, p. 343.

Modern economic progress is slowing for blacks relative to whites. Table 1 shows the unemployment rate of black males doubled the rate of white males and the unemployment rate of black females doubled the rate of white females. Juhn, Murphy and Pierce (1991) also show a slowdown in black-white wage convergence: in the Mid-1960's, Blacks earned 55\% of white hourly wages; in the late 1970's: Blacks earned 70\% of white hourly wages; and in the late 1980 's, Blacks earned $70 \%$ of white hourly wages.

New evidence from James Curtis Jr in Figure 1 and Figure 2 demonstrates persistent black-white differences in wealth $\&$ homeownership. Figure 1 demonstrates convergence in wealth levels through most of the 20th century until the start of the 21 st century, when stagnation in convergence is observed. 


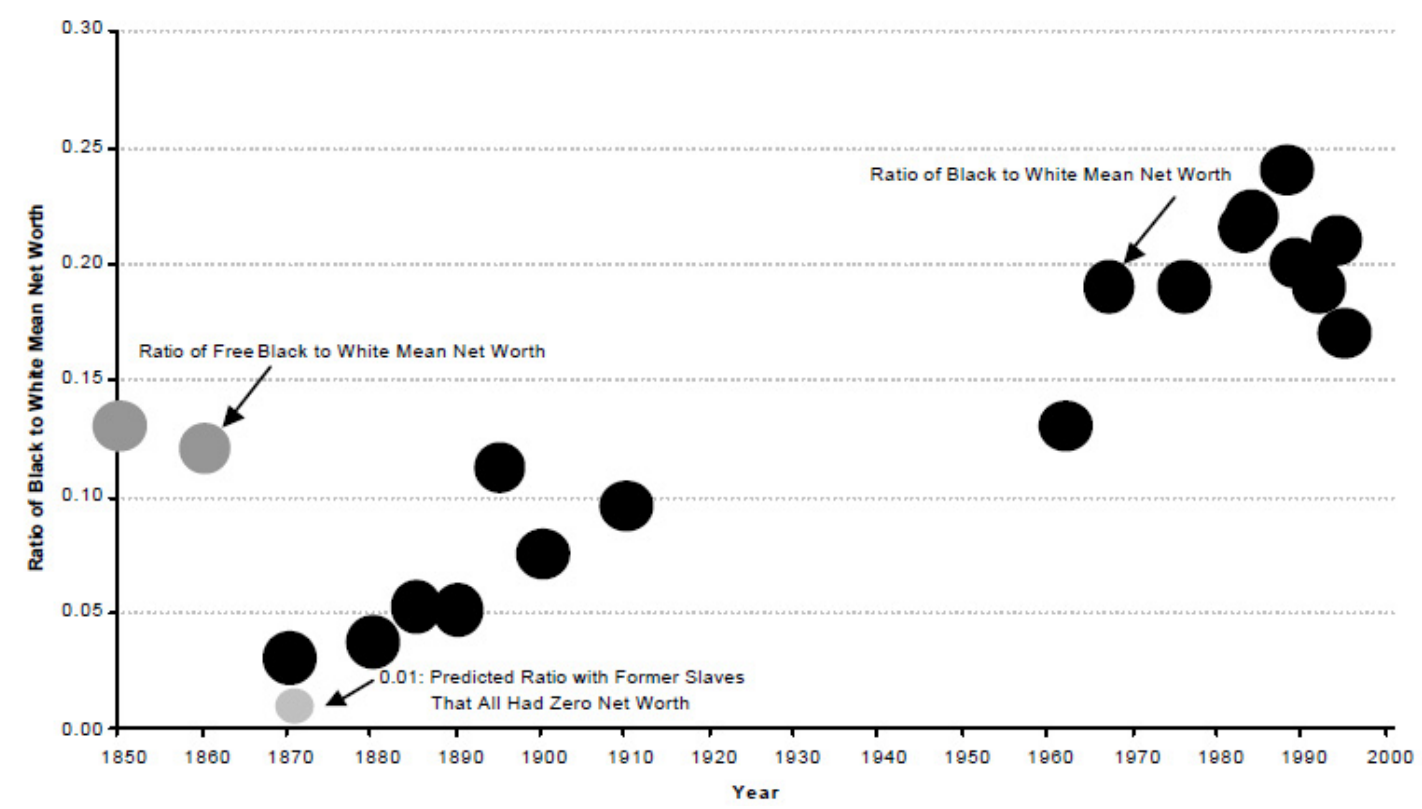

Figure 1. Ratio of black to white wealth/net worth, 1850-2000

Source: Metafile of Black-White Wealth Studies; 1850-70 IPUMS Data, James Curtis Jr.

Furthermore, stagnation in homeownership convergence occurred upon the beginning of the 21 st century.

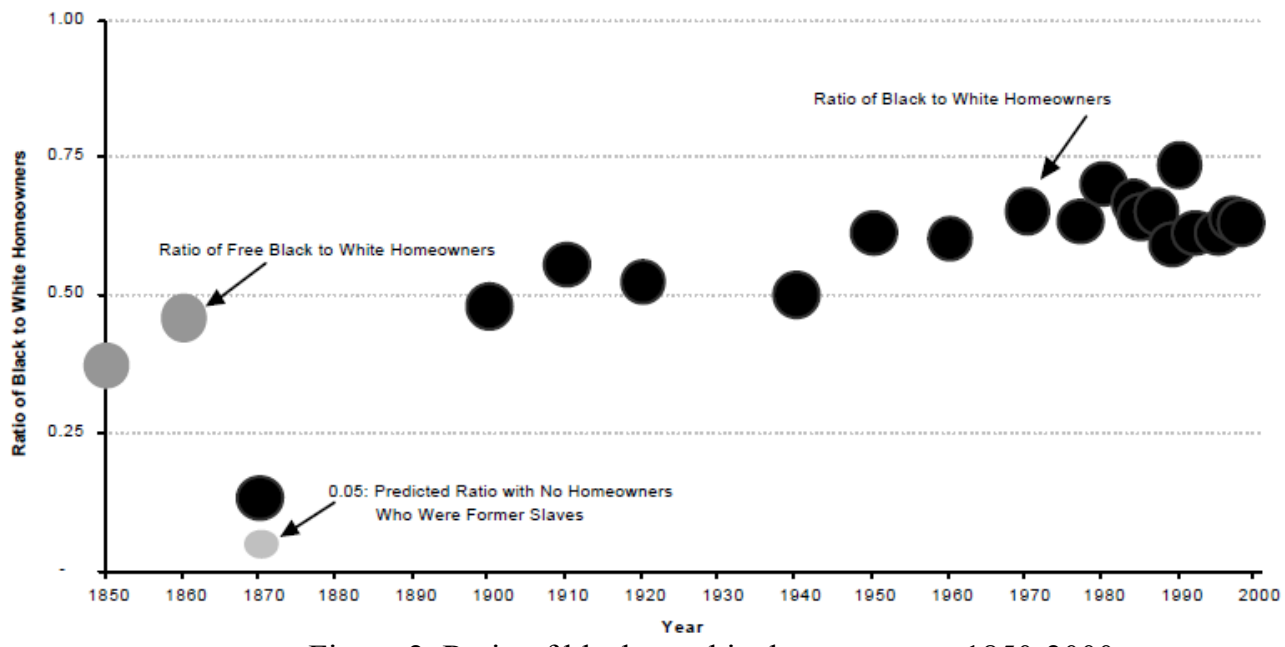

Figure 2. Ratio of black to white homeowners, 1850-2000

Source: Metafile of Homeownership Studies; 1850-70 IPUMS Data, James Curtis Jr.

Furthermore, Table 2 demonstrates observations by Melvin Oliver and Thomas Shapiro: large late-20th century differences in wealth among blacks and whites occurred across income groups. 
Table 2. Wealth across income \& race

\begin{tabular}{|c|c|c|c|c|c|c|}
\hline \multirow{3}{*}{$\begin{array}{l}\text { Income Groups } \\
\text { As } \% \text { of White }\end{array}$} & \multicolumn{4}{|c|}{ White } & \multicolumn{2}{|c|}{ Black } \\
\hline & \multirow{2}{*}{\multicolumn{2}{|c|}{$\frac{\text { Mean }}{(\$ 000)}$}} & \multicolumn{2}{|c|}{ Median } & \multicolumn{2}{|c|}{ Mean Median } \\
\hline & & & & $(\$ 000)$ & Ratio & Ratio \\
\hline \multicolumn{7}{|l|}{1983 Net Worth } \\
\hline Less than 10,799 & \multirow[t]{4}{*}{$\$$} & 35 & \multirow[t]{3}{*}{$\$$} & 11 & 0.25 & 0.01 \\
\hline $10,800-24,999$ & & 53 & & 29 & 0.35 & 0.15 \\
\hline $25,000-49,999$ & & 77 & & 50 & 0.42 & 0.36 \\
\hline More than 50,000 & & 197 & \multicolumn{2}{|r|}{114} & 0.39 & 0.49 \\
\hline \multicolumn{7}{|c|}{1983 Net Financial Assets: } \\
\hline Less than 10,799 & $\$$ & 14 & $\$$ & $\mathbf{0}$ & 0.05 & 0.00 \\
\hline $10,800-24,999$ & & 23 & & 3 & 0.15 & 0.00 \\
\hline $25,000-49,999$ & & 33 & & 6 & 0.20 & 0.00 \\
\hline More than 50,000 & & 126 & & 37 & 0.25 & 0.18 \\
\hline
\end{tabular}

Source: 1983-1984 CPS data reported in Table 6 on page 19 from Oliver and Shapiro, "Race and Wealth" in the Review of Black Political Economy, Spring 1989.

Juhn, Murphy and Pierce (1991) observed a sustained gap among blacks and whites with college degrees: in 1965: 13.9 percent of whites, compared to 4.6 percent of blacks had college degrees, producing a 9.3 percent gap; in 1975: 19.7 percent of whites, compared to 7.4 percent of blacks had college degrees, producing a 12.3 percent gap; and in 1985: 25.2 percent of whites, compared to 13.4 percent of blacks had college degrees, producing 11.8 percent gap. Many researchers suggest these type of schooling gaps explain differences in measured economic outcomes. However, Table 3 demonstrates large black-white wealth differences even when controlling for schooling differences.

Table 3. Wealth across age, income, education \& race

\begin{tabular}{lrrrr}
\hline Ratio of Black to White Wealth & \multicolumn{5}{c}{ Age of Head of Household } \\
Across Income \& Education Groups & Under 35 & $35-54$ & $55-64$ & Over65 \\
\hline \$5,000 in Family Income in 1967: & & & & \\
High School Diploma & 0.22 & 0.12 & 0.17 & 0.16 \\
Some College & 0.22 & 0.18 & 0.32 & 0.19 \\
College Degree + (less than 3\% of blacks) & 0.53 & 0.44 & 0.62 & 0.56
\end{tabular}

$\$ 10,000$ in Family Income in 1967:

$\begin{array}{lllll}\text { High School Diploma } & 0.25 & 0.14 & 0.20 & 0.18 \\ \text { Some College } & 0.25 & 0.21 & 0.36 & 0.22 \\ \text { College Degree + (less than 1\% of blacks) } & 0.63 & 0.50 & 0.71 & 0.64\end{array}$

$\$ 25,000$ in Family Income in 1967:

$\begin{array}{lllll}\text { High School Diploma } & 0.30 & 0.17 & 0.24 & 0.22 \\ \text { Some College } & 0.30 & 0.25 & 0.44 & 0.26 \\ \text { College Degree + (less than 1\% of blacks) } & 0.73 & 0.61 & 0.86 & 0.77\end{array}$

Source: 1967 SEO data reported in Table 5 on page 376 from Terrell, Wealth Accumulation of Black and White Families: The Empirical Evidence, Journal of Finance, 1971. 


\section{The Definition and Theory of Economic Discrimination}

\subsection{Discrimination}

Gregory Mankiw defines Discrimination as the offering of different opportunities to similar individuals who differ by color of skin, ethnicity, gender, age or other characteristic (Mankiw, 1997, p. 408).

\subsection{Statistical Discrimination}

Statistical Discrimination is making predictions about a person based on membership in a certain group (Stockton, 1999, p. 434), or using an individual's membership in a certain group as information on the individual's skill and productivity (Borjas, 2000, p. 357).

\subsection{Economic Discrimination [Practical Labor Market Discrimination]}

Practical labor market discrimination is based on observed and quantified outcomes in the economy; wide disparity in income, earnings, and wage rates among a variety of demographic groups, classified by gender, color, ethnicity and other characteristics. The disparities are systematic, persistent and considered by most observers to be inequitable (Cain, 1986, p. 694).

\subsection{Economic Discrimination [Theoretical Labor Market Discrimination]}

Theoretical labor market discrimination is the analysis under what conditions will essentially identical goods have different prices in the competitive markets? Discrimination in the labor market takes labor services as the good in question and the wage rate as the price. Labor services are considered essentially identical if they have the same productivity in the physical or material production process; a consideration that excludes the effect of the laborer on the psychic utility (or disutility) of his or her coworkers or employers (Cain, 1986, p. 695).

\subsection{Economic Discrimination [Becker Definition of Economic Discrimination]}

Gary Becker defines economic discrimination as the following: If an individual has a "taste for discrimination", he must act as if he were willing to pay something, either directly or in the form of reduced income, to be associated with some persons instead of others. Different levels of discrimination against a particular group are associated with: [a] different levels of social and physical distance from that group [which is the sociological analysis], [b] different personality types [which is the psychological analysis], and [c] separate factors of production. All persons who contribute to the production process in the same way are put into one group, such as the sale of labor services [which as the economic analysis] (Becker, 1957, p. 14).

Gary Becker presents a discrimination coefficient (d), which is defined as "tastes for discrimination" for different factors of production, employers and consumers. The money costs of a transaction do not always completely measure net costs and a discrimination coefficient acts as a bridge between money and net costs (Becker, 1957, p. 14). For instance, [a] A factor of production (or an employee) is offered a net money wage [w $-\mathrm{d}]$, [b] Employers pays a net rental rate of capital $[r+d]$, or [c] Consumers pay a net commodity price $[p+d]$.

Gary Becker also presents a market discrimination coefficient (MDC), which is the proportional difference in wage rates due to discrimination (Becker, 1957, p. 17). Consider the example of imperfect substitutes, where there are two groups, one and two, who are imperfect substitutes in the production process. Then, they may receive different wage rates even in the absence of discrimination $\left[\mathrm{w}_{1}{ }^{*} \neq \mathrm{w}_{2}{ }^{*}\right]$. A more general definition of the MDC sets the MDC equal to the difference between the ratio of two group's wage rates with discrimination $\left[\mathrm{w}_{1}\right.$ $\left.\neq \mathrm{w}_{2}\right]$ and without discrimination (Becker, 1957, p. 17). Then: $\mathrm{MDC}=\mathrm{w}_{1} / \mathrm{w}_{2}-\mathrm{w}_{1}{ }^{*} / \mathrm{w}_{2}{ }^{*}$.

Also, consider the example of perfect substitutes. Suppose there are two groups, one and two, whose members are perfect substitutes in the production process. In the absence of discrimination and nepotism and if the labor market were perfectly competitive, their equilibrium wage rates would equal $\left[\mathrm{w}_{1}{ }^{*}=\mathrm{w}_{2}{ }^{*}\right]$. However, equilibrium wage rates with discrimination cause wages not to equal $\left[\mathrm{w}_{1} \neq \mathrm{w}_{2}\right]$ (Becker, 1957, p. 17). Then, $\mathrm{MDC}=\mathrm{w}_{1} / \mathrm{w}_{2}-$ $\mathrm{w}_{1}{ }^{*} / \mathrm{w}_{2}{ }^{*}=\mathrm{w}_{1} / \mathrm{w}_{2}-\mathrm{w}_{2}{ }^{*} / \mathrm{w}_{2}{ }^{*}=\mathrm{w}_{1} / \mathrm{w}_{2}-1$.

We can rationally analyze labor market discrimination using economic theory, in the form of linear programming and the firm's optimization problem: 
Equation 1a: A presentation of the arrow model of discrimination

- Consider the following model, formalized by Arrow (1972), where owners of firms seek to maximize their utility, which includes short-run profits \& types of labor:

- Let: y = output produced by the firm

$$
\begin{aligned}
\mathrm{p}_{\mathrm{y}}= & \text { competitive market output price } \\
\mathrm{K}_{0}= & \text { fixed quantity of capital } \\
\mathrm{r} & =\text { competitive rental rate of capital } \\
\mathrm{L}_{1} & =\text { labor demanded from group one } \\
\mathrm{W}_{1}= & \text { wage paid to group one laborer } \\
\mathrm{L}_{2}= & \text { labor demanded from group two } \\
\mathrm{W}_{2}= & \text { wage paid to group two laborer } \\
\pi & =\text { profit earned by the firm } \\
\mathrm{U}= & \text { utility from earning profits }(+) \\
& \text { and employing members of } \\
& \text { group one (+) and group two (-) }
\end{aligned}
$$

- Firms choose $\mathrm{L}_{1}{ }^{*}$ and $\mathrm{L}_{2}{ }^{*}$ to:

$$
\begin{array}{ll}
\text { Max } & \mathrm{U}\left(\pi, \mathrm{L}_{1}, \mathrm{~L}_{2}\right) \\
\text { s.t. } & \pi=\mathrm{p}_{\mathrm{y}} \mathrm{y}-\mathrm{rK}_{\mathrm{o}}-\mathrm{w}_{1} \mathrm{~L}_{1}-\mathrm{w}_{2} \mathrm{~L}_{2} \\
\text { where } & \mathrm{y}=f\left(\mathrm{~K}_{\mathrm{o}}, \mathrm{L}\right) \\
& \mathrm{L}=\mathrm{L}_{1}+\mathrm{L}_{2} \\
& \partial \mathrm{U} / \partial \mathrm{L}_{1} \geq 0 \text { and } \partial \mathrm{U} / \partial \mathrm{L}_{2} \leq 0
\end{array}
$$$$
\Rightarrow \operatorname{Max} \mathrm{U}\left(\mathrm{p}_{y} f\left(\mathrm{~K}_{\mathrm{o}}, \mathrm{L}_{1}+\mathrm{L}_{2}\right)-\mathrm{rK}_{\mathrm{o}}-\mathrm{w}_{1} \mathrm{~L}_{1}-\mathrm{w}_{2} \mathrm{~L}_{2}, \mathrm{~L}_{1}, \mathrm{~L}_{2}\right)
$$

Equation 1c: The first order condition of the arrow model of discrimination for group 2

\section{- First Order Condition for group two (-):}

$$
\begin{aligned}
\frac{\partial U}{\partial L_{2}}: \frac{\partial U}{\partial \pi}\left[\frac{\partial \pi}{\partial f} * \frac{\partial f}{\partial L_{1}}-\frac{\partial \pi}{\partial L_{2}}\right]+\frac{\partial U}{\partial L_{2}} & =0 \\
\frac{\partial U}{\partial \pi}\left[\left(p_{y}\right)\left(M P L_{2}\right)-\left(w_{2}\right)\right]+\frac{\partial U}{\partial L_{2}} & =0 \\
{\left[\left(p_{y}\right)\left(M P L_{1}\right)-\left(w_{2}\right)\right] } & =-d_{2}
\end{aligned}
$$

where $d_{2}=\frac{\partial U}{\partial L_{2}} / \frac{\partial U}{\partial \pi} \leq 0$

$$
\text { Given: }\left[\left(p_{y}\right)\left(M P L_{2}\right)-\left(w_{2}\right)\right] \quad=-d_{2}
$$$$
\text { Then: } \quad p_{y} M P L_{2}=w_{2}-d_{2}
$$

For example: $\quad 50=40-(-10)$

Thus: Value of $M P L_{2}>w_{2}$
Equation 1b: The first order condition of the arrow model of discrimination for group 1

- Eirst Order Condition for group one (+):

$$
\begin{gathered}
\frac{\partial U}{\partial L_{1}}: \frac{\partial U}{\partial \pi}\left[\frac{\partial \pi}{\partial f} * \frac{\partial f}{\partial L_{1}}-\frac{\partial \pi}{\partial L_{1}}\right]+\frac{\partial U}{\partial L_{1}}=0 \\
\frac{\partial U}{\partial \pi}\left[\left(p_{y}\right)\left(M P L_{1}\right)-\left(w_{1}\right)\right]+\frac{\partial U}{\partial L_{1}}=0 \\
{\left[\left(p_{y}\right)\left(M P L_{1}\right)-\left(w_{1}\right)\right]=-d_{1}} \\
\text { where } d_{1}=\frac{\partial U}{\partial L_{1}} / \frac{\partial U}{\partial \pi} \geq 0 \\
\text { Given: }\left[\left(p_{y}\right)\left(M P L_{1}\right)-\left(w_{1}\right)\right] \\
\text { Then: } \quad p_{y} M P L_{1}=w_{1}-d_{1} \\
\text { For example: } 50=60-10 \\
\text { Thus : Value of } M P L_{1}<w_{1}
\end{gathered}
$$

Equation 1d: The interpretation of the arrow model of discrimination

- Wages - the discriminating firm offers wage rates s.t.:

$$
\begin{aligned}
w_{1} & >\text { value of marginal product of labor } & >w_{2} \\
\text { i.e. } 60 & >50 & >40
\end{aligned}
$$

or the discriminating firm offers members of group one a wage that exceeds the wage offered to members of group two even though the value of their marginal products are the same.

o Profits - Comparing profits from the discriminating firm $\left(\pi_{\mathrm{d}}\right)$ and non-discriminating firm $\left(\pi^{*}\right)$,

$$
\begin{aligned}
& \text { Given: } \pi=\mathrm{p}_{\mathrm{y}} \mathrm{y}-\mathrm{rK}_{\mathrm{o}}-\mathrm{w}_{1} \mathrm{~L}_{1}-\mathrm{w}_{2} \mathrm{~L}_{2} \\
& \\
& \mathrm{p}_{\mathrm{y}} \mathrm{MPL}_{1}=\mathrm{w}_{1}-\mathrm{d}_{1} \text { where } \mathrm{d}_{1} \geq 0 \\
& \mathrm{p}_{\mathrm{y}} \mathrm{MPL}_{2}=\mathrm{w}_{2}-\mathrm{d}_{2} \text { where } \mathrm{d}_{2} \leq 0
\end{aligned}
$$

Then:

$$
\begin{aligned}
& \pi_{\mathrm{d}}=\mathrm{p}_{\mathrm{y}} \mathrm{y}-\mathrm{rK}_{\mathrm{o}}-\left(\mathrm{p}_{\mathrm{y}} \mathrm{MPL}_{1}+\mathrm{d}_{1}\right) \mathrm{L}_{1}-\left(\mathrm{p}_{\mathrm{y}} \mathrm{MPL}_{2}+\mathrm{d}_{2}\right) \mathrm{L}_{2} \\
& \pi^{*}=\mathrm{p}_{\mathrm{y}} \mathrm{y}-\mathrm{rK}_{\mathrm{o}}-\left(\mathrm{p}_{\mathrm{y}} \mathrm{MPL}_{1} \quad\right) \mathrm{L}_{1}-\left(\mathrm{p}_{\mathrm{y}} \mathrm{MPL}_{2} \quad\right) \mathrm{L}_{2} \\
& \pi_{\mathrm{d}}-\pi^{*}=-\left(\mathrm{d}_{1} \mathrm{~L}_{1}+\mathrm{d}_{2} \mathrm{~L}_{2}\right) \\
& -([+]+[-]) \\
& \text { [ }- \text { ] }+ \text { [+] }
\end{aligned}
$$


Equation 1e: The profit conditions of the arrow model of discrimination

Case 1: No additional profits to discriminating $\left(\pi_{\mathrm{d}}=\pi^{*}\right)$

In this case, $d_{1} L_{1}=-d_{2} L_{2}$ and discrimination results in a transfer of resources from group two to group one (Arrow, 1972, p. 188).

Case 2: Negative profits due to discriminating $\left(\pi_{\mathrm{d}}<\pi^{*}\right)$

In this case, $d_{1} L_{1}>-d_{2} L_{2}$ and discrimination not only results in a net transfer of resources from group two to group one, but also a loss to owners of firms due to relatively larger preferences in favor of group one and the additional costs associated with these preferences.

Case 3: Positive profits due to discriminating $\left(\pi_{\mathrm{d}}>\pi^{*}\right)$

In this case, $d_{1} L_{1}<-d_{2} L_{2}$ and discrimination not only results in a transfer of resources from group two to group one, but a transfer of resources from group two to owners of firms due to relatively larger disutility from employing group two and the lower costs associated with this larger disutility.

Note that competition may encourage group two workers to work elsewhere and ultimately result in zero or negative profits for the discriminating firm. But employers may actually gain in pecuniary terms by their discrimination. Any individual employer would gain by a reduction in discrimination, but it is at least plausible that employers collectively gain by discrimination (Arrow, 1972, p. 189).

\section{Econometrics}

\subsection{Definition of Econometrics}

Econometrics "attempts to quantify economic reality and bridge the gap between the abstract world of economic theory and the real world of human activity ... Econometrics allows us to examine data and quantify the actions of firms, consumers and governments" (Studenmund, p. 3).

\subsection{Economic Theory}

Economic theory tells us about the anticipated direction (+/-) of changes in the economic environment. For example, theory suggests: An increase in income increases demand for goods; an increase in price decreases demand for goods.

\subsection{Econometric Modeling}

Econometric modeling allows us to measure the specific amount, or the magnitude of the change.

Consider following example: Let: $\mathrm{c}^{*}=[\mathrm{a} /(\mathrm{a}+\mathrm{b})][\mathrm{I} / \mathrm{p}]$ (from utility maximization); Then, $\ln (\mathrm{c})=\ln [\mathrm{a} /(\mathrm{a}+\mathrm{b})]+$ $\ln (\mathrm{I})-\ln (\mathrm{p})$ such that the econometric or regression model is $\ln (\mathrm{c})=B_{o}+B_{1}{ }^{*} \ln (\mathrm{I})-B_{2}{ }^{*} \ln (\mathrm{p})+$ error.

\section{Simple Regression Model versus the Multivariate Regression Model}

The simple regression model implies a dependent variable (c) is only explained by one independent variable, which is not realistic. For example, quantity (c) consumed is not just explained by price (p). The multivariate regression model implies a dependent variable (c) is explained by more than one independent variable, which is more realistic. For example, the combination of price (p) and income (I) explain quantity consumed (c).

\section{Slopes $\left(\mathbf{B}_{\mathbf{s}}\right)$}

The only difference between the simple and multivariate regression models is the calculation and the interpretation of the slope. The slope $\left(B_{k}\right)$ from the multivariate regression model is the change in the dependent 
variable associated with a one-unit change in the independent variable, holding constant the other independent variables in the equation: $\ln (\mathrm{c})=B_{o}+B_{1}{ }^{*} \ln (\mathrm{I})+B_{2}{ }^{*} \ln (\mathrm{p})+$ error.

When using logs of the dependent variable, a slope becomes the elasticity and units become percentages.

\subsection{Hypothesis Testing}

Hypothesis Testing are statistical tests, such as t-tests, on the accuracy of slopes calculated in an econometric model before accepting the results. In the way in which the FDA withholds approval of a new medication that has a side effect more frequently than expected, economists withhold "accepting" a calculated coefficient until it pasts certain statistical or hypothesis tests (Studenmund, 1999, p. 126).

\subsubsection{Sample Survey Data}

A hypothetical survey is two questions to six families: How many meals does your family consume at restaurants per year? What is you annual family income? The hypothetical results of the survey are presented in Table 4 .

Table 4. A Hypothetical survey of 6 families, annual income and restaurant meals/year

\begin{tabular}{lll}
\hline Family No. & $\begin{array}{l}\text { No. of Restaurant Meals } \\
\text { Per Year }\end{array}$ & $\begin{array}{l}\text { Annual Income } \\
(\$ 1000)\end{array}$ \\
1 & 50 & 12 \\
2 & 70 & 13 \\
3 & 70 & 14 \\
4 & 50 & 9 \\
5 & 80 & 16 \\
6 & 40 & 8 \\
\hline
\end{tabular}

\subsubsection{Least Squares}

The line that "best fits" the data minimizes difference between the fitted line and the data. Let $\mathrm{e}_{\mathrm{i}}$ be the difference between the one point on the line and one data point, then the smallest sum of $e_{i}$ 's seems to produce the best fitted line. But the smallest sum of $\mathrm{e}_{\mathrm{i}}$ 's can produce more than one estimate of the slope the line. Instead, by summing the square of each $\mathrm{e}_{\mathrm{i}}$, we can obtain one estimate of the slope. Hence, the line that "best fits" the data is a "least squares" regression line that minimizes the sum of squared error.

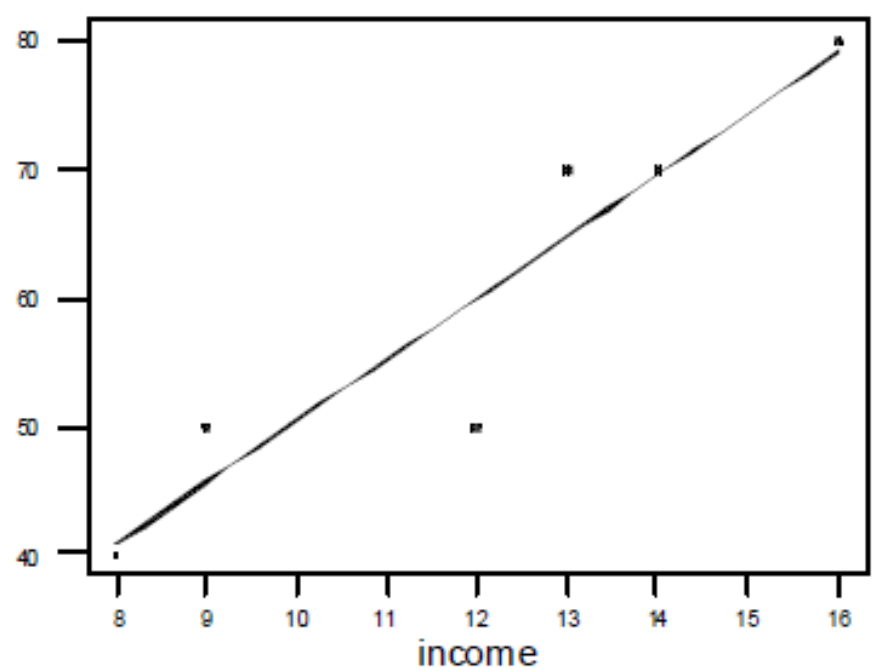

Figure 3. The fitted line from the hypothetical survey which minimizes the sum of squared error

Source: Data Analysis from James Curtis Jr (2001). 
From utility maximization $\mathrm{c}^{*}=[\mathrm{a} /(\mathrm{a}+\mathrm{b})][\mathrm{I} / \mathrm{p}]$ such that $\ln (\mathrm{c})=\ln [\mathrm{a} /(\mathrm{a}+\mathrm{b})]+\ln (\mathrm{I} / \mathrm{p})$. Normalizing the price to 1 , and analyzing the data in levels produces $c=B_{0}+B_{1} I+$ error, where $B_{o}$ is the y-intercept or "constant": The constant tells us how many restaurant meals that we would still consume if we have zero income $(I=0)$. $B_{1}$ is the slope of the fitted line: The slope tells us the change in the number of restaurant meals consumed we could expect with a one unit change in the value of annual income.

\subsection{Empirical Results}

Empirical results are the output from the econometric model and statistical software (or calculations using a calculator), where $\mathrm{c}=2.6+4.78 \mathrm{I}$ and where estimated $\mathrm{B}_{\mathrm{o}}=2.6$. Thus, we can predict that families will visit restaurants 2.6 times annually even if they have zero annual income. Estimated $\mathrm{B}_{1}=4.78$. Thus, we can predict that the number of annual restaurant visits increase by 4.78 with one unit (one thousand dollar) increase in annual income.

\section{Measurements of Economic Discrimination}

We can apply these lessons from econometrics to measure economic discrimination. Ronald Oaxaca (1973) mechanized empirical analysis of economics discrimination even though we do not have direct data on preferences in favor of group one, or the disutilities of employing group two. Oaxaca (1973) used Becker's (1957) market discrimination coefficient to conduct regression decomposition, known as the Oaxaca decomposition. The market discrimination coefficient (MDC) can be analyzed in terms of wages and income when members of group one and group two are perfect substitutes. Given: $\mathrm{MDC}=\left(\mathrm{w}_{1}-\mathrm{w}_{2}\right) / \mathrm{w}_{2}=\mathrm{w}_{1} / \mathrm{w}_{2}-1$, then: $\ln (\mathrm{MDC})=\ln \left(\mathrm{w}_{1}\right)-\ln \left(\mathrm{w}_{2}\right)$. Differences in wealth can be analyzed using the MDC with additional theoretical considerations (Curtis Jr, 2002).

Using an econometric model for wages, income or wealth $\left(\mathrm{w}_{\mathrm{i}}\right)$, then $\ln \left(\mathrm{w}_{1}\right)=\mathrm{B}_{\mathrm{o} 1}+\mathrm{B}_{11} \mathrm{Z}_{1}+$ error ${ }_{1}$ and $\ln \left(\mathrm{w}_{2}\right)=$ $\mathrm{B}_{\mathrm{o} 2}+\mathrm{B}_{12} \mathrm{Z}_{2}+$ error 2 where $\mathrm{Z}$ is a matrix of variables that determine wages, income or wealth. To form the regression decomposition, combine the $\log \mathrm{MDC}$ and the econometric model.

Equation 2a: A presentation of regression decomposition based on the arrow theory of economic discrimination

- To form the regression decomposition, combine the log $\mathrm{MDC}$ and the econometric model such that:

$$
\begin{aligned}
& \text { Given: } \ln (\mathrm{MDC})=\ln \left(\mathrm{w}_{1}\right)-\ln \left(\mathrm{w}_{2}\right) \\
& \ln \left(\mathrm{w}_{\mathrm{i}}\right) \quad=\mathrm{B}_{\mathrm{oi}}+\mathrm{B}_{1 \mathrm{i}} \mathrm{Z}_{\mathrm{i}}+\text { error }_{\mathrm{i}} \\
& \text { Then: } \ln (\mathrm{MDC})=\left(\mathrm{B}_{\mathrm{o} 1}+\mathrm{B}_{11} \mathrm{Z}_{1}+\text { error }_{1}\right) \\
& -\left(\mathrm{B}_{\mathrm{o} 2}+\mathrm{B}_{12} \mathrm{Z}_{2}+\text { error }_{2}\right) \\
& \ln (\mathrm{MDC})=\left(\mathrm{B}_{\mathrm{o} 1}-\mathrm{B}_{\mathrm{o} 2}\right) \\
& +\left(B_{11} Z_{1}-B_{12} Z_{2}\right) \\
& +\left(\text { error }_{1}-\text { error }_{2}\right) \\
& \text { Let: } \quad B_{11}=B_{12}+\left(B_{11}-B_{12}\right) \\
& Z_{2}=Z_{1}+\left(Z_{2}-Z_{1}\right) \\
& \text { Then: } \ln (\mathrm{MDC})=\left(\mathrm{B}_{\mathrm{o} 1}-\mathrm{B}_{\mathrm{o} 2}\right) \\
& +\left[\mathrm{B}_{12}+\left(\mathrm{B}_{11}-\mathrm{B}_{12}\right)\right] \mathrm{Z}_{1} \\
& -\mathrm{B}_{12}\left[\mathrm{Z}_{1}+\left(\mathrm{Z}_{2}-\mathrm{Z}_{1}\right)\right] \\
& +\left(\text { error }_{1}-\text { error }_{2}\right)
\end{aligned}
$$

Equation 2b: The interpretation of regression decomposition based on the arrow theory of economic discrimination

$$
\begin{aligned}
& \text { Then: } \ln (\mathrm{MDC})=\left(\mathrm{B}_{\mathrm{o} 1}-\mathrm{B}_{\mathrm{o} 2}\right) \\
& +\mathrm{B}_{12} \mathrm{Z}_{1}+\left(\mathrm{B}_{11}-\mathrm{B}_{12}\right) \mathrm{Z}_{1} \\
& \left.-B_{12} Z_{1}+B_{12}\left(Z_{2}-Z_{1}\right)\right] \\
& +\left(\text { error }_{1}-\text { error }_{2}\right) \\
& \text { Then: } \ln (\mathrm{MDC})=\left(\mathrm{B}_{01}-\mathrm{B}_{02}\right)+\left(\mathrm{B}_{11}-\mathrm{B}_{12}\right) \mathrm{Z}_{1} \\
& +\mathrm{B}_{12}\left(\mathrm{Z}_{2}-\mathrm{Z}_{1}\right) \\
& +\left(\text { error }_{1}-\text { error }_{2}\right)
\end{aligned}
$$

where $B_{12}\left(Z_{2}-Z_{1}\right)$ $\begin{aligned}= & \text { Explained differences in wages, income or } \\ & \text { wealth (due to differences in skills) }\end{aligned}$ 


\section{Regression Decomposition Results}

Empirical results of differences in economic outcomes between enfranchised groups and disenfranchised groups demonstrate significant unexplained differences in economic outcomes, even when controlling for classical choice characteristics.

\subsection{Male and Female Wages}

Oaxaca (1973) found 53 percent to 78 percent of wage differences among white males and white females in the United States were unexplained and 50 percent to 99 percent of wage differences among black males and black females in the United States were unexplained.

\subsection{Black and White Wages}

Determinants of gender and ethnic wages differences are comparable. Binder (1973) found 30 percent to 45 percent of wage differences among males and females in the United States were unexplained. Similarly, 20 percent to 35 percent of wage differences among blacks and whites in the United States were unexplained. Furthermore, Carlstom and Rollow (1998) found 37 percent to 39 percent of wage differences among blacks and whites in the United States were unexplained.

Carlstrom and Rollow (1998) also observed fair wage premium for blacks residing in non-southern states: they found 37 percent of wage differences among non-southern blacks and non-southern whites in the United States were unexplained, 44 percent of wage differences among southern blacks and southern whites in the United States were unexplained.

Nevertheless, this is preliminary evidence that the fair wage issue for females is, at least, proportional to the fair wage issue for blacks.

\subsection{Black and White Housing Prices}

Differences in the determinants of housing values were also observed and blacks and whites in the United States: 41 percent to 42 percent of differences in housing values among blacks and whites in the United States were unexplained (Long \& Caudill, 1992).

\subsection{Black and White Wealth}

The analysis of differences in the determinants of the wealth by ethnicity is, at least as revealing or, more revealing than the analysis of wages and income. Becker (1957) and Arrow (1972) developed the most general theories of wage discrimination and favoritism. Oaxaca (1973) and Blinder (1973) have mechanized their theories for empirical analysis. While their findings are insightful, they cannot be directly applied to studying wealth differences since wealth is a complex combination of wages and other variables.

The purpose of wealth has varied from over time. From an economics perspective, wealth is the accumulation of resources that have market value and can be liquidated for present and future consumption. This study proceeds based on the most measurable assumption: households reside in a country with a mixed economy of markets and social planning, such that they have an incentive to accumulate material wealth for intertemporal household consumption and social influence. Appendix A contextualizes wealth regression decomposition results with models of grouped household decisions and social planner decisions. Appendix B contextualizes wealth regression decomposition results with models of a group-specific analysis of household wealth.

Most academic research has found that three out of every four US dollars of wealth held by white households represents the difference among blacks and whites in the United States which is unexplained. Blau and Graham (1990) found that 78 percent of differences in wealth among blacks and whites in the United States were unexplained in the late 20th Century. Similarly, Altonj, Doraszeski and Segal (2000) found that 70 percent to 94 percent of differences in wealth among blacks and whites in the United States were unexplained. Furthermore, Gittleman and Wolff (2000) found that 68 percent to 72 percent of differences in wealth among blacks and whites in the United States were unexplained.

James Curtis Jr (December, 2002) confirms that the source of contemporary black-white wealth differences have historical roots: 82 percent to 86 percent of differences in wealth among blacks and whites in the United States were unexplained by classical choice characteristics in the mid-19th century. Curtis $\operatorname{Jr}$ (2002) also observed a quasi-fairness wealth premium for blacks residing in non-southern states (i.e., states which abolished slavery before mass emancipation of southern slaves or states which never officially instituted slavery as a social practice): 78 percent of differences in wealth among blacks and whites in the non-southern states in the United States were unexplained while 88 percent of differences in wealth among blacks and whites in former southern slave states in the United States remained unexplained by classical choice characteristics. 
Much like "the plight of the antebellum free black American, which, in hindsight, illuminated the path of the average black American after emancipation" (Curtis Jr, February, 2002), the experience of blacks in non-southern states, as early as 1870 , provided insight to the experience of the contemporary Americans of diverse experiences attempting achieve the pursuit of happiness.

\section{Reflections and Conclusions}

Historical black-white differences in wealth were estimated using regression decomposition. This technique decomposes economic differences into the portion explained by differences in characteristics and the unexplained portion due to different returns to a set of characteristics (See, e.g., Blinder, 1973; Oaxaca, 1973). Reflecting on the analyses of James Curtis Jr (2002), results confirm that we cannot reject that the claim that, when comparing the wealth of ex-slaves to the wealth whites, differences in wealth due to unexplained (or discrimination) effects dominate the portion due to classical characteristic differences.

Furthermore, the size and source of contemporary black-white wealth differences have historical roots: In 1870, at least 75 percent of white-black wealth differences were not explained by characteristic differences described by the classical model when employing the primary index. This is consistent with wealth decompositions of late twentieth century data that shows that three-quarters of white-black differences in wealth were unexplained (See, e.g., Blau \& Graham, 1990).

Finally, since unexplained differences in states that abolished slavery after the Civil War were 10 percent higher than unexplained effects in states that abolished slavery well before the Civil War and the magnitudes of the unexplained effects were similar over the long-run, we cannot reject the existence of a negatively bounded correlation between the duration of time from enslavement and the magnitude of unexplained differences in wealth.

\section{References}

Altonji, Joseph G., \& Rebecca M. Blank. (1999). Race and Gender in the Labor Market. In Orley Ashenfelter \& David Card (Eds,), Handbook of Labor Economics (Vol. 3C, pp. 3143-3260). https://doi.org/10.1016/S1573-4463(99)30039-0

Altonji, Joseph G., Ulrich Doraszelski, \& Lewis Segal. (2000). Black/White Differences in Wealth. Federal Reserve Bureau of Chicago Economic Perspectives, 24(1), 38-50.

Arrow, Kenneth. (1972). Some Mathematical Models of Race in the Labor Market. In A. H. Pascal (Ed.), Racial Discrimination in Economic Life (pp. 187-204). Lexington, MA: Lexington Books.

Ashenfelter, Orley, \& John Ham. (1979, October). Education, Unemployment and Earnings. Journal of Political Economy, 87(5), S99-116. https://doi.org/10.1086/260824

Attack, Jeremy, \& Fred Bateman. (1981, March). Egalitarianism, Inequality, and Age: The Rural North in 1860. Journal of Economic History, 41, 85-93. https://doi.org/10.1017/S0022050700042807

Becker, Gary S. (1957). The Economics of Discrimination. Chicago: Chicago.

Birnbaum, Howard, \& Rafael Weston. (1974, March). Homeownership and the Wealth Position of Black and White Americans. Review of Income and Wealth, 20(1), 103-118. https://doi.org/10.1111/j.1475-4991.1974.tb00911.x

Blau, Francine, \& John Graham. (1990, May). Black-White Differences in Wealth and Asset Composition. Quarterly Journal of Economics, 105(2), 321-339. https://doi.org/10.2307/2937789

Blinder, Alan. (1973). Wage Discrimination: Reduce Form and Structural Estimates. Journal of Human Resources, 8(4), 436-455. https://doi.org/10.2307/144855

Borjas, George. (2000). Labor Economics. McGraw-Hill.

Cain, Glen G. (1986). The Economic Analysis of Labor Market Discrimination: A Survey. In Orley Ashenfelter \& Richard Layard (Eds.), Handbook of Labor Economics (Vol. 1, pp. 693-785). Amsterdam: North-Holland.

Carlstrom, Charles T., \& Rollow, Christy D. (1998). Regional Variations in White-Black Earnings. Federal Reserve Bank of Cleveland Economic Review (2nd Quarter), 34(2), 10-22.

Chiteji, Ngina, \& Frank Stafford. (1999, May). Portfolio Choices of Parents as Young Adults: Asset Accumulation by African American Families. American Economic Review: Papers and Proceedings of the One Hundred Eleventh Annual Meeting of the American Economic Association, 89(2), 377-380. 
Coelho, Philip R., \& James F. Shepherd. (1974, September). Differences in Regional Prices: The United States, 1851-1880. Journal of Economic History, 34(3), 551-591. https://doi.org/10.1017/S0022050700079808

Collins, William, \& Robert Margo. (1999, August). Race and Homeownership (Working Paper No. 7277). National Bureau of Economic Research.

Conley, Dalton, \& Being Black. (1999). Living in the Red: Race Wealth, and Social Policy in America. Berkeley: University of California.

Conley, Timothy G., David Galenson, \& Steven Herscovici. (1995, November). Economic Opportunity in Urban America: Region, Nativity and Wealth in the Mid-Nineteenth Century (working paper).

Cramer, Clayton E. (1997). Black Demographic Data, 1790-1860: A Sourcebook. Westport: Greenwood.

Curry, Leonard. (1981). The Free Black in Urban America, 1800-1850: The Shadow of the Dream. Chicago: Chicago University Press.

Curtis Jr, James Edward. (2002, December 1). Long-Run Differences in Wealth: A Microdata Analysis of US White-Black Differences in Wealth Directly after Mass Emancipation of Southern Slaves. SSRN Working Paper Number 1701373. Retrieved from http://ssrn.com/abstract=1701373

Curtis Jr, James Edward. (2010, November 11). Institutional and Agency Effects on the Status of Free Blacks: Synthesizing Asymmetrical Laws and Social Conditions with Asymmetrical Economic Outcomes. SSRN Working Paper Number 1701423. Retrieved from http://ssrn.com/abstract=1701423

DuBois, W. E. B. (1899). The Philadelphia Negro: A Social Study. New York: Schocken.

Easterlin, Richard A. (1961). Regional Income Trends, 1840-1950. In American Economic History (pp. 525-547). New York: McGraw-Hill.

Easterlin, Richard A. (1968). Population, Labor Force, and Long Swings in Economic Growth: The American Experience. New York: NBER.

Eblen, Jack E. (1972, July). Growth of the Black Population in Ante Bellum America, 1820-1860. Population Studies, 26(2), 273-289. https://doi.org/10.2307/2173582

Eggert, Gerald. Two-Steps Forward, a Step and a Half Back: Harrisburg's African American Community in the Nineteenth Century. In Joe Trooter Jr., Pennsylvania (Ed.), African Americans in Pennsylvania: Shifting Historical Perspectives (pp. 220-253). Pennsylvania State University.

Feagin, Joe R. (1998). Slavery Unwilling to Die: The Background of Black Oppression in the 1980s. In The New Urban Paradigm. Rowman and Littlefield: Lahman.

Franklin, John H. (1943). The Free Negro in North Carolina, 1790-1860. New York: Russell.

Franklin, Stephen D., \& James D. Smith. Black-White Differences in Income and Wealth. American Economic Review: Papers and Proceedings of the Eighty-ninth Annual Meeting of the American Economic Association, 67(1), 405-409.

Gittleman, Maury, \& Edward N. Wolff. (2000, August). Racial Wealth Disparities: Is the Gap Closing. Social Science Research Network Working Paper No. 311.

Greene, Lorenzo J., \& Carter G. Woodson. (1930). The Negro Wage Earner. Washington: Association for the Study.

Greene, William. (1997). Econometric Analysis. New Jersey: Princeton Hall.

Ham, John. (1982, July). Estimation of a Labor Supply Model with Censoring Due to Unemployment and Underemployment. Review of Economic Studies, 52.

Herscovici, Steven. (1995, October). Migration and Economic Mobility: Wealth Accumulation and Occupational Change Among Antebellum Migrants and Non-Migrants (working paper).

Higgs, Robert. (1982, September). Accumulation of Property by Southern Blacks Before World War I. American Economic Review, 72(2), 725-737.

Hirsch Jr., Leo H. (1931, October). The Free Negro in New York. Journal of Negro History, 16(4), 415-453. https://doi.org/10.2307/2713871

Holmes, George K. (1893, December). The Concentration of Wealth. Political Science Quarterly, 8(4), 489-600. https://doi.org/10.2307/2140099 
Hoover, Ethal D. (1958, September). Wholesale and Retail Prices in the Nineteenth Century. The Journal of Economic History, 18(3), 298-316. https://doi.org/10.1017/S0022050700107181

Hornsby, Anne. (1989, Winter). The Accumulation of Wealth by Black Georgians, 1890-1915. Journal of Negro History, 74(1), 11-30. https://doi.org/10.1086/JNHv74n1-4p11

Hurst, Erik, Ming Ching Luoh, \& Frank Stafford. (1998). The Wealth Dynamics of American Families, 1884-94. Brookings Papers on Economic Activity, 1, 267-337. https://doi.org/10.2307/2534673

Jackson, Luther Porter. (1939, October). The Virginia Free Negro Farmer and Property Owner. Journal of Negro History, 24(4), 390-439. https://doi.org/10.2307/2714362

Jackson, Ronald V. (1991). Index to the Eighth Census of the United States. Salt Lake City: Accelerated Indexing Systems International.

Jain, Sushil Kumar. (1967). The Negro in Canada: A Selected List of Primary and Secondary Sources for the Study of Negro Community in Canada from the Earliest Times to the Present Days. Canada: University of Saskatchewan.

Juhn, Chinhoi, Kevin M. Murphy, \& Brooks Pierce. (1991). Accounting for the Slowdown in Black-White Wage Convergence. In Marvin H. Kosters (Ed.), Workers and Their Wages. DC: American Enterprise Institute.

Kain, John F., \& John Quigley. (1972, January). Housing Market Discrimination, Homeownership, and Savings Behavior. American Economic Review, 62(3), 263-277.

Kotlikoff, Laurence J., \& Lawrence H. Summers. (1981). The Role of Intergenerational Transfers in Aggregate Capital Accumulation. Journal of Political Economy, 89(4), 706-732. https://doi.org/10.1086/260999

Leiman, Melvin M. (1993). Political Economy of Racism. Pluto: London.

Long, James E., \& Steven B. Caudill. (1992, January). Racial Differences in Homeownership and Housing Wealth, 1970-1986. Economic Inquiry, 83-100. https://doi.org/10.1111/j.1465-7295.1992.tb01537.x

MacCurdy, Thomas E. (1981, December). An Empirical Model of Labor Supply in a Life-Cycle Setting. Journal of Political Economy, 89(6). https://doi.org/10.1086/261023

Magnuson, Diana L. (1995). The Making of a Modern Census: The United States Census of Population, 1790-1940 (Doctoral Dissertation). University of Minnesota.

Magnuson, Diana L. Who and What Determined the Content of the U.S. Population Schedule Over Time. Historical Methods, 28(1), 11-26.

Magnuson, Diana L., \& Miriam L. King. (1995, Winter). Comparability of the Public Use of Microdata Samples: $\begin{array}{lllll}\text { Enumeration } & \text { Procedures. } & \text { Historical } & \text { Methods, } & \text { 28(1), }\end{array}$ https://doi.org/10.1080/01615440.1995.9955310

Mankiw, Gregory. (1997). Principles of Microeconomics. McGraw-Hill.

Margo, Robert. (1984, September). Accumulation of Property by Southern Blacks Before World War I: Comment and Further Evidence. American Economic Review, 74(4), 768-774.

Margo, Robert. (1990). Race and Schooling in the South: 1880-1915, An Economic History. Chicago: University of Chicago Press. https://doi.org/10.7208/chicago/9780226505015.001.0001

Masson, Andre. (1986, March). A Cohort Analysis of Wealth-Age Profiles Generated by a Simulation Model in France (1949-75). The Economic Journal, 96(381), 173-190. https://doi.org/10.2307/2233432

Mechlinger, Louis R. (1916, June). The Attitude of the Free Negro Toward Colonization. Journal of Negro History, 1(3), 276-301. https://doi.org/10.2307/3035624

Melden, Charles. From Slave to Citizen (pp. 199-205). New York: The Methodist Book Concern.

Menchik, Paul, \& Nancy Jianakopolis. (1997, April). Black-White Wealth Inequality: Is Inheritance the Reason? Economic Inquiry, 35, 428-442. https://doi.org/10.1111/j.1465-7295.1997.tb01920.x

Miller, Kelly. (1922, January-June). Enumeration Errors in the Negro Population. Scientific Monthly, 14, 168-177.

Mincer, Jacob. (1958, August). Investments in Human Capital and Personal Income Distribution. Journal of Political Economy, 66, 281-302. https://doi.org/10.1086/258055

Mincer, Jacob. (1974). Schooling, Experience and Earnings. NBER: New York. 
Mirer, Thad W. (1979, June). The Wealth-Age Relation Among the Aged. American Economic Review, 69(3), 434-443.

Moldigiani, Franco, \& Richard Brumberg. (1955). Utility Analysis and the Consumption Function: An Interpretation of Cross-Section Data. In Kenneth Kurihara (Ed.), Post-Keynesian Economics. London: George Allen.

Oaxaca, Ronald, \& Michael Ransom. (1994, March). On Discrimination and the Decomposition of Wage Differentials. Journal of Econometrics, 61, 3-21. https://doi.org/10.1016/0304-4076(94)90074-4

Oaxaca, Ronald, \& Michael Ransom. (1999, February). Identification in Detailed Wage Decompositions. Review of Economics and Statistics, 154-57. https://doi.org/10.1162/003465399767923908

Oaxaca, Ronald. (1973). Male-Female Wage Differences in Urban Labor Markets. International Economic Review, 14(3), 693-709. https://doi.org/10.2307/2525981

Oliver, Melvin L. Race, \& Wealth. (1989, Spring). Review of Black Political Economy, 71(4), 5-25. https://doi.org/10.1007/BF02910814

Oliver, Melvin L., \& Thomas M. Shapiro. (1997). Black Wealth/White Wealth: A Perspective of Racial Inequality. New York: Routledge.

Pennsylvania Abolition Society. (1838). The Present State and Condition of the People of Color of the City of Philadelphia and Adjoining Districts. Philadelphia.

Pope, Clayne L. (1989). Households on the American Frontier: The Distribution of Income and Wealth in Utah, 1850-1900. In David W. Galenson (Ed.), Markets in History: Economic Studies of the Past. Cambridge: Cambridge.

Ruggles Steven, \& Matthew Sobek. (1997). Integrated Public Use Microdata Series: Version 2.0. Minneapolis: Historical Census Projects. University of Minnesota.

Ruggles, Steven, \& Russell R. Menard. (1995, Winter). The Minnesota Historical Census Projects. Historical Methods, 28(1), 6-10. https://doi.org/10.1080/01615440.1995.9955308

Ruggles, Steven, et al. (1995, Winter). General Design of the Integrated Public Use Microdata Series. Historical Methods, 28(1), 31-39. https://doi.org/10.1080/01615440.1995.9955311

Segal, Lewis M., \& Daniel G. Sullivan. (1998). Trends in Homeownership: Race, Demographics, and Income. Federal Reserve Bureau of Chicago Economic Perspectives, 2, 52-72.

Sherman, Howard J. (1996). A Holistic-Evolutionary View of Racism, Sexism, and Class Inequality. In William Dugger (Ed.), Inequality: Radical Institutionalist Views on Race, Gender, Class, and Nation. Greenwood: Connecticu.

Shulman, Steven. (1996). Racial Inequality and Radical Institutionalism: A Research Agenda. In William Dugger (Ed.), Inequality: Radical Institutionalist Views on Race, Gender, Class, and Nation. Greenwood: Connecticut.

Snyder, Donald C. (1989, Spring). A Database with Income and Assets of New Retirees by Race and Hispanic Origin. Review of Black Political Economy, 1(4), 5-25.

Society of Friends. (1849). Statistical Inquiry into the Condition of the Free People of the City and Districts of Philadelphia. Philadelphia.

Soltow, Lee. (1972). A Century of Personal Wealth Accumulation. In Harold G. Vatter \& Thomas Palm (Eds.), The Economics of Black America (pp. 80-84). New York: Harcourt Brace Jovanovich.

Soltow, Lee. (1975). Men \& Wealth in the United States. New Haven: Yale.

Spriggs, William Edward. (1984). Afro-American Wealth Accumulation, Virginia, 1900-1914 (Ph.D. Dissertation). University of Wisconsin at Madison.

Steckel, Richard H. (1988, Spring). Census Matching and Migration: A Research Strategy. Historical Methods, 21(2), 52-60. https://doi.org/10.1080/01615440.1988.9955280

Steckel, Richard H. (1991, Winter). The Quality of Census Data for Historical Inquiry: A Research Agenda. Social Science History, 579-599. https://doi.org/10.1017/S0145553200021313

Steckel, Richard H., \& Carolyn Moehling. (2000, January). Wealth Inequality in Industrializing New England: New Evidence and Tests of Competing Hypothesis. Journal of Economic History. 
https://doi.org/10.3386/h0122

Steckel, Richard. (2000, January). The African American Population of the United States, 1790-1920. In A Population History of North America.

Stockman, Alan C. (1999). Introduction to Microeconomics. Fort Worth: Dryden.

Studenmund, A. H. (1999). Using Econometrics: A Practical Guide. Addison-Wesley.

Swinton, David H. Racial Discrimination: A Labor Force Competition Theory of Discrimination in the Labor Market. American Economic Review: Papers and Proceedings of the Eighty-ninth Annual Meeting of the American Economic Association, 67(1), 400-404.

Terrell, Henry S. (1971, May). Wealth Accumulation of Black and White Families: The Empirical Evidence. Journal of Finance: Papers and Proceedings from the Twenty-Sixth Annual Meeting of the American Finance Association, 26(2), 363-377. https://doi.org/10.2307/2326053

The Christian Life: New Testament, Master Outlines and Study Notes, New King James Version. (1982). Nashville: Thomas Nelson.

The Holy Bible, Contemporary English Version. (1995). New York: American Bible Society.

The Holy Bible, King James Version. (1942). Philadelphia: AJ Holman.

The Holy Bible, King James Version. (1988). Colorado Springs: International Society.

The Holy Bible, King James Version. London, Cambridge University.

The Holy Bible, New International Version. (1984). (Hard Cover). Colorado Springs: International Bible Society, The Holy Bible, New International Version. (1984). (Soft Cover). Colorado Springs: International Bible Society.

The Holy Bible, The Everywhere Bible, New International Version. (2006). Grand Rapids: Zondervan.

The Holy Bible, New King James Version. (1982). Thomas Nelson.

The NKJV Study Bible, New King James Version. (1997). Nashville: Thomas Nelson.

US Bureau of the Census, Negro Population, 1790-1915. (1918). Washington: Government Printing Office.

US Census Office, The Eighth Census of the United States: 1860. (1864). Washington: Government Printing Office.

Weiss, Thomas. (1992). U.S. Labor Force Estimates and Economic Growth, 1800-1860. In Robert E. Gallman \& John Wallis (Eds.), American Economic Growth and Standards of Living Before the Civil War (pp. 19-78). Chicago: University of Chicago.

Wolff, Edward. (1992, May). Changing Inequality of Wealth. American Economic Review: Papers and Proceedings of the One Hundred and Fourth Annual Meeting of the American Economic Association, 82(2), 552-558.

Wolff, Edward. (1998, Summer). Recent Trends in the Size Distribution of Household Wealth. Journal of Economic Perspectives, 12(3), 131-150. https://doi.org/10.1257/jep.12.3.131

Wolff, Edward. (2001). Racial Wealth Disparities: Is the Gap Closing? Levy Institute Public Policy Brief No. 66.

Woods, Letitia. (1972). Free Negroes in the District of Columbia, 1790-1846. New York: Oxford.

Woodson, Carter G. (1924). Free Negro Owners of Slaves in the United States in 1830. New York: Negro Universities.

Woodson, Carter G. (1968). The Education of the Negro Prior to 1861. New York: Arno.

Wright, Carroll D. (1900). The History and Growth of the United States Census. Washington: Government Printing Office.

Wright, James M. (1971). The Free Negro in Maryland, 1634-1860. New York: Octagon.

Yitzhaki, Schlomo. (1987, February). The Relation between Return and Income. Quarterly Journal of Economics, 77-95. https://doi.org/10.2307/1884681 


\section{Appendix A}

\section{Agent-Specific Constraints}

$$
\begin{aligned}
& \operatorname{MAX} / \mathbf{x}_{n i j} \geq 0 / \mathbf{U}=\gamma_{\mathbf{U}} \prod_{S P=1} \boldsymbol{U}_{\mathrm{SP}}{ }^{\theta_{(S P)}} \\
& \text { subject to } \mathbf{X}_{i j S P} \leq \mathbf{E}_{i j S P} \\
& \text { Let: } \quad \quad \quad \boldsymbol{U}_{\mathrm{SP}}=\gamma_{\boldsymbol{U}(S P)} \prod_{j=1}\left(\prod_{i=1} \boldsymbol{u}_{i j(S P)} \theta_{i j(S P)}\right) \\
& \text { such that } \quad \mathbf{U}=\boldsymbol{\gamma}^{*} \prod_{S P=1}\left[\prod_{j=1}\left(\prod_{i=1} \boldsymbol{u}_{i j(S P)} \boldsymbol{\theta}^{\circ}\right)\right] \\
& \text { where } \quad \gamma^{*}=\gamma_{\mathrm{U}} \Pi_{S P=1} \gamma_{U(S P)} \\
& \boldsymbol{\theta}^{*}=\theta_{i,(S P)} \theta_{(S P)} \\
& \text { Further, let: } \quad \quad \quad \boldsymbol{u}_{j S P}=\gamma_{u j i S P} \Pi_{n=1}\left(\mathbf{x}_{(n) i j}-s_{\mathbf{x}(n) i j S P}\right)^{\alpha_{(n)}} \\
& \text { such that } \quad \mathbf{U}=\boldsymbol{\gamma} \prod_{S P=1}\left[\prod_{j=1}\left(\prod_{i=1}\left(\prod_{n=1}\left(\mathbf{x}_{(n) i j}-s_{\mathbf{x}(n) j S P}\right)^{\left.\alpha(n)^{\prime}\right)}\right)\right]\right. \\
& \text { where } \quad \gamma^{\prime}=\gamma_{U}\left[\prod_{S P=1} \gamma_{U(S P)}\left(\prod_{j=1}\left(\prod_{i=1} \gamma_{u j S P}\right)\right)\right] \\
& \boldsymbol{\alpha}(\mathbf{n})^{\prime}=\alpha(n) \theta_{i j(S P)} \theta_{(S P)} \\
& \text { Further, let: } \quad \mathbf{E}_{i j S P}=\sum_{n=1} \boldsymbol{p}_{\mathbf{x}(n)} e_{\mathbf{x}(n) j) S P}+\boldsymbol{p}_{\mathbf{x}(1)} e_{\mathbf{x}(l) j i j}+e_{i j S P} \quad \text { for all } n=1,2, \ldots, E \quad \neq \quad 1 \\
& \text { Further, let: } \quad \mathbf{X}_{i j}=\sum_{n=1} \boldsymbol{P}_{\mathbf{x}(n))} \boldsymbol{x}_{(n) i j}+\boldsymbol{p}_{\mathbf{x}(())} \mathbf{X}_{(1) i j} \\
& \text { where } \quad \boldsymbol{P}_{\mathbf{x}(n) j}=\boldsymbol{p}_{\mathbf{x}(n)}\left(1+\delta_{\mathbf{x} j g}+\sum_{q=1} t_{q \mathbf{x}(n)}^{\prime}\right) \\
& \boldsymbol{P}_{\mathbf{x}(\mathrm{E})}=\eta(\mathrm{B})
\end{aligned}
$$

Therefore, the decision becomes:

$$
\begin{aligned}
& \left.\mathbf{M A X} / \mathbf{x}_{n i j} \geq 0\right\} \mathbf{U}=\boldsymbol{\gamma} \prod_{S P=1}\left[\prod_{j=1}\left(\prod_{i=1}\left(\prod_{n=1}\left(\mathbf{x}_{n i j}-s_{\mathbf{x}(n) j S P}\right)^{\alpha_{\left(n n^{\prime}\right.}}\right)\right)\right] \\
& \text { subject to } \sum_{n=1} \boldsymbol{P}_{\mathbf{x}(n) j} \mathbf{x}_{(n) i j}+\boldsymbol{p}_{\mathbf{x}(l))} \mathbf{x}_{(1) j} \leq \sum_{n=1} \boldsymbol{p}_{\mathbf{x}(n)} e_{\mathbf{x}(n) i j S P}+\boldsymbol{p}_{\mathbf{x}(1)} e_{\mathbf{x}(l) j i}+e_{i j S P} \\
& \text { Further, let: } \quad \sum_{n=1} \boldsymbol{p}_{\mathbf{x}(n)} e_{\mathbf{x}(n) j i j P}+\sum_{v=1} \mathbf{w}_{v} \boldsymbol{h}_{v i j}=\mathbf{w}_{i j} \\
& \text { where } \quad \boldsymbol{w}_{\mathrm{v}}=\boldsymbol{p}_{\mathbf{x}())} \\
& \boldsymbol{h}_{v i j}=e_{x(l) j i}-x_{(l) i j}
\end{aligned}
$$

\section{One Universal Constraint}

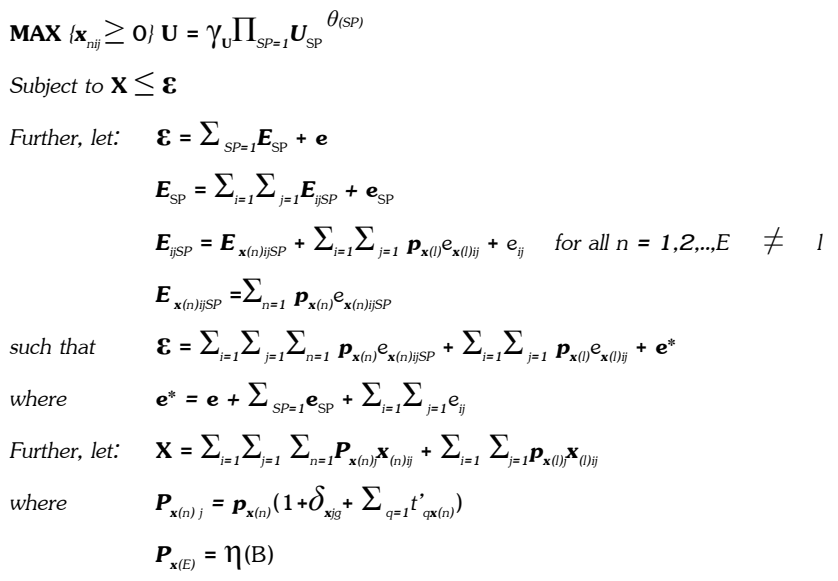

Therefore, the decision becomes:

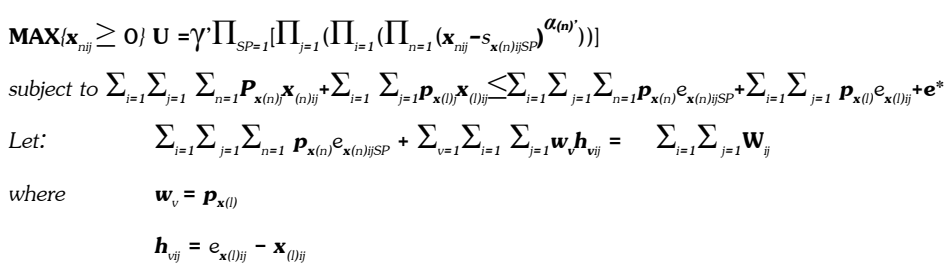

\section{A Model of Wealth}

$$
\text { Let: } \quad \begin{aligned}
\mathbf{W}_{i j} & =\left(1-g-\sum_{q=1} t_{q l}\right)_{i j}+\mathbf{A}_{i j}+(1-g)\left(\sum_{q=1} S_{q j}+C_{i j}\right)-G_{i j} \\
\mathbf{I}_{i j} & =\sum_{v=1} \boldsymbol{w}_{m}^{\prime} \boldsymbol{h}_{k i j}^{\prime} \\
\boldsymbol{w}_{m}^{\prime} & =\boldsymbol{w}_{k}-\delta_{w(m) j g}-\sum_{q=1} t_{q}^{\prime} \\
\boldsymbol{h}_{m i j}^{\prime} & =\boldsymbol{h}_{m i j}-\delta_{h(m) j g}
\end{aligned}
$$




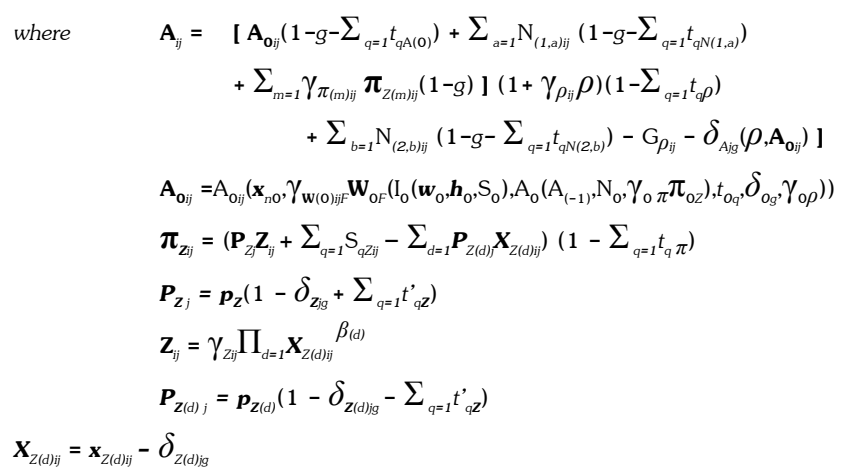

\section{Appendix B}

\section{A Model of Wealth Favoritism}

To understand the determinants of wealth by groups, consider the following wealth identity:

$$
W_{w, t}=\exp \left\{\left(1+i_{w}\right) W_{w, t-1}+\left(r_{w, t} h_{w t}-p_{t} c_{w, t}\right)\right\}
$$

where $W_{w t}$ represents the portfolio of wealth for members of group $w$, at time $\mathrm{t}=1 \ldots \mathrm{T}$; $W_{w, t-1}$ represents the previous period portfolio of wealth for members of group $w$, at time $\mathrm{t}=0 \ldots \mathrm{T}-1 ; i_{w}$ represents the average interest rate earned on previous period portfolio of wealth for members of group $w$, at time $t=1 \ldots \mathrm{T} ; r_{w, t}$ represents the wages for group $w$, at time $t=1 \ldots \mathrm{T} ; h_{w, t}$ represents the number of hours worked for members of group $w$, at time $\mathrm{t}=1 \ldots \mathrm{T} ; p_{t}$ represents prices for goods consumed at time $\mathrm{t}=1 \ldots \mathrm{T}$; and $c_{w, t}$ represents the goods consumed by members of group $w$, at time $\mathrm{t}=1 \ldots \mathrm{T}$; such that:

$$
W_{w, t}=\exp \left\{\sum_{\tau=1}^{t}\left(1+i_{w}\right)^{t-\tau}\left(r_{w, \tau} h_{w, \tau}-p_{\tau} c_{w, \tau}\right)+\left(1+i_{w}\right)^{t} W_{w, o}\right\}
$$

where $W_{w, o}$ are the initial assets of whites.

Now consider the wealth identity with discrimination or, more specifically, favoritism in favor of members of group $w$. Let $\delta_{k, w, \tau}$ represent the variable $k$ favoritism coefficient for members of group $w$, at time $\tau=1 \ldots \mathrm{T}$, where $\delta_{k, w, \tau}>0$ for all variables, such that equation [2] becomes: 
[ 3 ] $\quad W_{w, t}=\exp \left\{\widetilde{W}_{w t}+F_{w, t}\right\}$

where

$$
\begin{aligned}
& \tilde{W}_{w, t}=\sum_{\tau=1}^{t}\left(1+\tilde{i}_{w}\right)^{t-\tau}\left(\tilde{r}_{w, \tau} \tilde{h}_{w, \tau}-p_{\tau} \tilde{c}_{w, \tau}\right)+\left(1+\tilde{i}_{w}\right)^{t} \tilde{W}_{w, o} \\
& F_{w, t}=\delta_{i, w} \sum_{m=1}^{t-\tau} \sum_{s=1}^{t-\tau}\left(1+\widetilde{i}_{w}+\delta_{i, w}\right)^{t-m-1}\left(1+\widetilde{i}_{w}\right)^{s-1} . \\
& \cdot\left(\tilde{r}_{w, \tau} \tilde{h}_{w, \tau}+\widetilde{r}_{w, \tau} \delta_{h, w, \tau}+\delta_{r, w, \tau} \tilde{h}_{w, \tau}+\delta_{r, w, \tau} \delta_{h, w, \tau}-p_{\tau}\left(\tilde{c}_{w, \tau}+\delta_{c, w, \tau}\right)\right) \\
& +\delta_{i, w} \sum_{m=1}^{t} \sum_{s=1}^{t}\left(1+\widetilde{i}_{w}+\delta_{i, w}\right)^{t-m}\left(1+\widetilde{i}_{w}\right)^{s}\left(\widetilde{W}_{w, o}+\delta_{W_{o}, w}\right) \\
& +\sum_{\tau=1}^{t}\left(1+\tilde{i}_{w}\right)^{t-\tau}\left(\delta_{r, w, \tau}\left(\tilde{h}_{w, \tau}+\delta_{h, w, \tau}\right)-p_{\tau} \delta_{c, w, \tau}\right)+\left(1+\tilde{i}_{w}\right)^{t} \delta_{W_{o}, w}
\end{aligned}
$$

where tilda represents the variable in absence of discrimination such that $\tilde{W}_{w, t}$ is group $w$ in absence of discrimination (favoritism) at time $\tau=1 \ldots \mathrm{T}$, and $F_{w, t}$ is the difference between the observed wealth and wealth in absence of discrimination due to favoritism for members of group $w$ at time $\tau=1 \ldots$ T. The following comparative static analysis shows what happens to wealth with an increase in discrimination, such that:

[ 4 ] $\frac{\partial \ln W_{w, t}}{\partial \delta_{r, w, \tau}}=\left[\sum_{\tau=1}^{t}\left(1+\tilde{i}_{w}\right)^{t-\tau}+\delta_{i, w} \sum_{m=1}^{t-\tau} \sum_{s=1}^{t-\tau}\left(1+\tilde{i}_{w}+\delta_{i, w}\right)^{t-m-1}\left(1+\tilde{i}_{w}\right)^{s-1}\right] h_{w, \tau} \quad>0$ 


$$
\begin{aligned}
& \text { [ } 5 \text { ] } \frac{\partial \ln W_{w, t}}{\partial \delta_{h, w, \tau}}=\left[\sum_{\tau=1}^{t}\left(1+\widetilde{i}_{w}\right)^{t-\tau}+\delta_{i, w} \sum_{m=1}^{t-\tau} \sum_{s=1}^{t-\tau}\left(1+\widetilde{i}_{w}+\delta_{i, w}\right)^{t-m-1}\left(1+\widetilde{i}_{w}\right)^{s-1}\right] r_{w, \tau} \quad>0 \\
& \text { [ 6 ] } \frac{\partial \ln W_{w, t}}{\partial \delta_{c, w, \tau}}=-\left[\sum_{\tau=1}^{t}\left(1+\widetilde{i}_{w}\right)^{t-\tau}+\delta_{i, w} \sum_{m=1}^{t-\tau} \sum_{s=1}^{t-\tau}\left(1+\widetilde{i}_{w}+\delta_{i, w}\right)^{t-m-1}\left(1+\widetilde{i}_{w}\right)^{s-1}\right] p_{\tau} \quad<0
\end{aligned}
$$

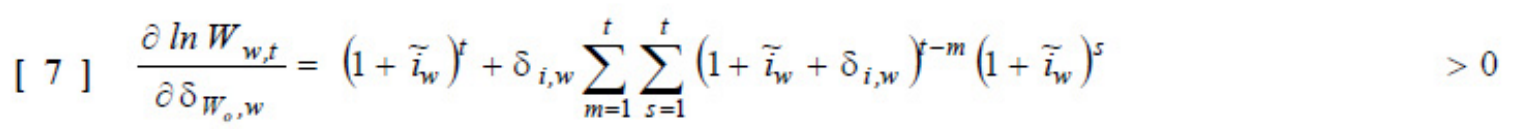

$$
\begin{aligned}
& \text { [ } 8 \text { ] } \frac{\partial \ln W_{w, t}}{\partial \delta_{i, w, \tau}}=\sum_{\tau=1}^{t}(t-\tau+1)\left(1+\tilde{i}_{B}+\delta_{i, w}\right)^{t-\tau}\left(r_{w, \tau} h_{w, \tau}-p_{\tau} c_{w, \tau}\right) \\
& +\sum_{\tau=1}^{t} \tau\left(1+\tilde{i}_{w}+\delta_{i, w}\right)^{\tau-1} W_{w, o}
\end{aligned}
$$

Equation [4] shows that the size of the increase in log wealth due to a unit increase in wage favoritism depends on the size of the rate of return, compounded through time, and the number of hours worked. Similarly, equation [5] also shows that the size of the increase in $\log$ wealth due to a unit increase in hours-worked favoritism depends on the size the wage rate and the compounded rate of return. Furthermore, equation [6] shows that the size of the reduction in $\log$ wealth due to a unit increase in consumption favoritism depends on the size of the price of commodity consumption and the compounded rate of return. Note that equation [7] shows that the size of the increase in $\log$ wealth due to a unit increase in initial wealth discrimination depends solely on the size of the compounded rate of retum. Finally, equation [8] shows that the size of the 
increase in $\log$ wealth due to a unit increase in interest rate discrimination depends on the size of initial wealth, periodic savings, and the compounding rate of return.

\section{A Model of Wealth Discrimination}

Analogous to equation [2], we can write for blacks:

[ 9 ]

$$
W_{B, t}=\exp \left\{\sum_{\tau=1}^{t}\left(1+i_{B}\right)^{t-\tau}\left(r_{B, \tau} h_{B, \tau}-p_{\tau} c_{B, \tau}\right)+\left(1+i_{B}\right)^{t} W_{B, o}\right\} .
$$

where $W_{B, t}$ represents the portfolio of wealth for black, $B$, at time t=1... T

$W_{B, t-1}$ represents the previous period portfolio of wealth for blacks, $B$, at time $\mathrm{t}=0 \ldots \mathrm{T}-1$;

$i_{B}$ represents the average interest rate eamed on previous period portfolio of wealth for

blacks, $B$, at time $\mathrm{t}=1 \ldots \mathrm{T} ; r_{B, t}$ represents the wages for blacks, $B$, at time $\mathrm{t}=1 \ldots \mathrm{T} ; h_{B, t}$

represents the number of hours worked for blacks, $B$, at time $\mathrm{t}=1 \ldots \mathrm{T} ; p_{t}$ represents

prices for goods consumed at time $\mathrm{t}=1 \ldots \mathrm{T}$; and $c_{B, t}$ represents the goods consumed by

blacks, $B$, at time t $=1 \ldots \mathrm{T}$, and where $W_{B, o}$ is the initial assets of blacks.

Now consider the wealth identity with discrimination or, more specifically, pure

discrimination in against members of group $B$. Let $\widetilde{\delta}_{k, B, \tau}$ represent the variable $k$

favoritism coefficient for members of group $B$, at time $\tau=1 \ldots \mathrm{T}$, where $\tilde{\delta}_{k, B, \tau}<0$ for all variables, such that equation [4] becomes $^{2}$ :

${ }^{2}$ Let $\tilde{\delta}_{k, B, \tau}=-\delta_{k, B, \tau}$ where $\delta_{k, B, \tau}>0$ 


$$
\begin{aligned}
& \text { [12] } \frac{\partial \ln W_{B, t}}{\partial \delta_{h, B, \tau}}=-\left[\sum_{\tau=1}^{t}\left(1+\widetilde{i}_{B}\right)^{t-\tau}-\delta_{i, B} \sum_{m=1}^{t-\tau} \sum_{s=1}^{t-\tau}\left(1+\widetilde{i}_{B}-\delta_{i, B}\right)^{t-m-1}\left(1+\widetilde{i}_{B}\right)^{s-1}\right] r_{B, \tau}>0 \\
& \text { [ } 13 \text { ] } \frac{\partial \ln W_{B, t}}{\partial \delta_{c, B, \tau}}=\left[\sum_{\tau=1}^{t}\left(1+\widetilde{i}_{B}\right)^{t-\tau}-\delta_{i, B} \sum_{m=1}^{t-\tau} \sum_{s=1}^{t-\tau}\left(1+\widetilde{i}_{B}+\delta_{i, B}\right)^{t-m-1}\left(1+\widetilde{i}_{B}\right)^{s-1}\right] p_{\tau} \quad>0 \\
& \text { [ 14] } \frac{\partial \ln W_{B, t}}{\partial \delta_{W_{o}, B}}=-\left[\left(1+\widetilde{i_{B}}\right)^{t}-\delta_{i, B} \sum_{m=1}^{t} \sum_{s=1}^{t}\left(1+\widetilde{i_{B}}+\delta_{i, B}\right)^{t-m}\left(1+\widetilde{i_{B}}\right)^{s}\right] \quad<0 \\
& \text { [ 15] } \frac{\partial \ln W_{B, t}}{\partial \delta_{i, B, \tau}}=-\sum_{\tau=1}^{t}(t-\tau+1)\left(1+\tilde{i}_{B}-\delta_{i, B}\right)^{t-\tau}\left(r_{B, \tau} h_{B, \tau}-p_{\tau} c_{B, \tau}\right) \\
& -\sum_{\tau=1}^{t} \tau\left(1+\widetilde{i}_{B}-\delta_{i, B}\right)^{\tau-1} W_{B, o}
\end{aligned}
$$

Equation [11] shows that the size of the decrease in log wealth due to a unit increase in wage discrimination depends on the size of the rate of return, compounded through time, and the number of hours worked. Similarly, equation [12] also shows that the size of the reduction in log wealth due to a unit increase in hours-worked discrimination depends on the size the wage rate and the compounded rate of return. Note that equation [13] shows that a unit increase in consumption discrimination can overstate wealth, especially if consumption is forced below subsistence. The size of this effect depends on the price of the commodity and the compounded rate of return from savings in each period

Furthermore, equation [14] shows that the size of the decrease in log wealth due to a unit increase in initial wealth discrimination depends solely on the size of the compounded rate of return. Finally, equation [15] shows that the size of the decrease in 
$\log$ wealth due to a unit increase in interest rate discrimination depends on the size of initial wealth, periodic savings, and the compounding rate of return.

\section{A Model of Relative Wealth}

In theory, the average wealth of group $B$ is some proportion of the average wealth of group $w$, such that,

[ 16]

$$
\bar{W}_{w, t}=\left(\frac{1}{\phi}\right) \bar{W}_{B, t}
$$

where $1 / \phi$ is the theoretical proportion of wealth. If $\phi$ equals one, then the average wealth of group $B$ is the same the average wealth of $w$. As $\phi$ goes to zero, the average wealth of $w$ becomes infinity times the average wealth of group $B$. As $\phi$ goes to infinity, the average wealth of group $w$ becomes an infinitesimal proportion of the average wealth of the average wealth of group $B$. Let $\phi=e^{-(\lambda \Gamma+\gamma \Lambda)}$, then,

$$
\begin{aligned}
& \frac{\partial \bar{W}_{w, t}}{\partial \Gamma}=\lambda \phi \bar{W}_{B, t} \\
& \frac{\partial \bar{W}_{w, t}}{\partial \Lambda}=\gamma \phi \bar{W}_{B, t}
\end{aligned}
$$

such that,

$$
\begin{aligned}
& \lambda=\sigma+\gamma \\
& \text { where } \sigma=\phi \bar{W}_{B, t}\left(\frac{\partial \bar{W}_{w, t}}{\partial \Gamma}-\frac{\partial \bar{W}_{w, t}}{\partial \Lambda}\right)
\end{aligned}
$$




\section{Appendix C}

\section{Studies of Late 20th Century Data}

Andrew Brimmer (1988) found that blacks held 7.2 percent of US aggregate income, but only 3 percent of US aggregate wealth in 1984. This large disparity in wealth have persisted throughout the twentieth century: Between 1940 and 1988, the black mean was 13 to 23 percent of white mean, and the black median 4 to 10 percent of white median (Wolff, 1992). But the origin of these differences has not been researched. Several studies (See, e.g., Pennsylvania Abolitionist Society, 1838; Society of Friends, 1849; Dubois, 1899; Jackson, 1939; Soltow, 1972; Soltow, 1975; Berlin, 1979; Higgs, 1982; Spriggs, 1984; Margo, 1984; Hornsby, 1989; Eggert, 1997; Hershberg, 1997; Bodenhorn, 1999) have addressed historical differences in wealth. However, their results are often limited by non-representative local samples, small samples, or descriptive analyses that do not employ potential explanatory variables.

Lee Soltow $(1972,1975)$ conducted one of the first in-depth studies of overall mid-nineteenth century wealth accumulation patterns using the census population schedules. Note that these schedules were originally stored on microfilms. He spun the microfilm half-turns to collect random, cross-sectional samples from 1850-1870. Soltow used Gini coefficients to find that black wealth was less equally distributed among blacks than white wealth among whites. He finds that "their inequality levels are strangely similar in the sense that a few held wealth" (Soltow, 1975, p. 145). Note that Soltow employs a small sample of 393 non-whites (1975) and 151 blacks (1972) to calculate his results.

\section{Studies of 19th Century and Early 20th Century Data}

Several studies have analyzed the experience blacks prior to the mass emancipation of southern slaves. John Hope Franklin (1943), Leon Litwick (1961) and Ira Berlin (1974) provide comprehensive accounts of free blacks. Furthermore, Philadelphia Abolitionist Society (1838), Society of Friends (1849), Dubois (1899), Eggert (1997) and Hershberg (1997) provided original studies on free black wealth in localities within Pennsylvania. Also, Bodenhorn (1999) studied racial inequality by analyzing wealth differences among darker and lighter free blacks in Maryland, Virginia, North Carolina, Kentucky and Louisiana. But free blacks were only two percent of the US population at any given time period.

Several studies have analyzed black-white wealth differences among in the south well after emancipation. Robert Higgs (1982), Robert Margo (1984) and Anne Hornsby (1989) used tax records to analyze southern black-white wealth differences between 1865 and 1915. They found strong yet limited wealth grains among blacks after emancipation although their results are limited the southern economy. Researchers have also studied different aspects of white-black wealth differences using contemporary data For instance, several studies have focused on white-black wealth differences due to differences in inheritance (See, e.g., Kotlikoff \& Summers, 1981; Menchik \& Jianakopolis, 1997; Wolff, 1998; Altonji, Doraszelski, \& Segal, 2000). Other studies have focused on white-black wealth differences due to differences in income, savings and preferences (See, e.g., Terrell, 1971; Franklin \& Smith, 1977; Oliver \& Shapiro, 1989; Wolff, 1992; Oliver \& Shapiro, 1997; Conley, 1999; Keister, 2000a; Keister, 2001; Wolff, 2001). Additional studies have focused on white-black wealth differences due to differences in assets and homeownership (See, e.g., Terrell 1971; Birmbaum \& Weston, 1974; Brimmer, 1988; Snyder, 1989; Wolff, 1992; Wolff, 1998; Hurst, Luoh, \& Stafford, 1998; Chiteji \& Stafford, 1999; Keister, 2000b).

Several studies attempt assess the dominant source of wealth and wealth differences. Kotlikoff and Summers (1981) produced a foundational study on aggregate wealth and found that intergenerational transfers were the most significant factor in wealth accumulation. Conely (1999) proposed that legal and class barriers were the source of black-white wealth differences.1. Blau and Graham (1990) produced a seminal study of racial wealth inequality using regression decomposition. After controlling for income and demographic variables, they found that 78 percent of the wealth gap remained unexplained in 1976.

These studies have made significant contributions to our understanding of economic discrimination in terms of modern wealth differences. This study will build upon their findings by analyzing white-black wealth differences directly after the Civil War and mass emancipation of southern slaves to obtain new insights into the historical and intertemporal dimensions of the white-black wealth gap.

\section{James Curtis Jr (2002) Studies of 19th Century Wealth Using the United Stated Census}

The 1870 census manuscripts contain responses to important socioeconomic inquiries including age, sex, color, marital status, literacy status, whether the individual attended school during the year, occupation, state or country of birth, value of real estate, and value of personal estate (other forms of wealth) for all individuals in a given 
household.

Real estate value was enumerated based on guidelines specified in the Circular to Marshals. It specified that "under heading 8 insert the value of real estate owned by each individual enumerated. You are to obtain the value of real estate by inquiry of each individual who was supposed to own real estate, be the same located where it may, and insert the amount in dollars. No abatement of the value is to be made on account of any lien or encumbrance thereon in the nature of debt" (Magnuson, 1995, p347). Personal estate value (other wealth) was also enumerated based on guidelines that specified "Personal estate is to be inclusive of all bonds, stocks, mortgages, notes, live stock, plate, jewels, or furniture, but exclusive of wearing apparel" (p. 349). For more on the quality of historical census data (see Wright, 1900; Steckel, 1991; Magnuson, 1995).

Note that sample includes the reported wealth of household heads. Enumerators only recorded the value of wealth if an individual had more than 100 dollars in nominal wealth. Furthermore, zero wealth is not equivalent to zero dollar-wages per hour, where one must account for the participation decision to obtain robust estimates. Instead, not having any initial wealth, savings, and assets leads to one possessing zero wealth.

\section{Copyrights}

Copyright for this article is retained by the author(s), with first publication rights granted to the journal.

This is an open-access article distributed under the terms and conditions of the Creative Commons Attribution license (http://creativecommons.org/licenses/by/4.0/). 